\title{
THE BANNATYNE CLUB AND THE PUBLICATION OF SCOTTISH ECCLESIASTICAL CARTULARIES
}

During the course of the nineteenth century the Abbotsford, Bannatyne, Grampian, Maitland, and Spalding Clubs, together with a number of individuals, were responsible for publishing the majority of the documents that related to the Scottish medieval church. ${ }^{2}$ Although they all devoted a great deal of time and effort in making the papers more accessible in printed form to the general public, the Bannatyne Club undoubtedly made the greatest contribution. Two points differentiate it from its contemporaries and successors. First, the sheer scale of its publishing operation over a relatively short period of time. Second, the importance to successive generations of historians of Scotland of the records of the individual religious houses that it published. These consisted of a series of texts now commonly regarded, and used, as the cartularies of some of the major Scottish religious houses, including Arbroath, Brechin, Dunfermline, Kelso, Melrose, Moray, and Scone.

Most historians working in the field of Scottish medieval history nowadays would acknowledge that they owe a huge debt to these clubs and societies for making so many documents available in print for future generations. Historians have, however, in their gratitude perhaps been guilty of accepting these published cartularies uncritically. ${ }^{3}$ To date, nobody has delved too deeply into the methodologies employed by the editors of these volumes when they converted the source material into publishable form. Generations of historians have placed a huge burden of trust upon the accuracy and editorial skills of the men who were employed as editors by the Bannatyne Club. In this

\footnotetext{
${ }^{1}$ My thanks to Dauvit Broun, Sonja Cameron and Grant G. Simpson for commenting upon an earlier draft of this paper and to Aonghas MacCoinnich for finding a cache of Innes papers in the Mitchell Library, Glasgow. Thanks are also due to the National Archives of Scotland and to the University of Edinburgh Library for permission to reproduce material.

${ }^{2}$ The circumstances surrounding both the formation and the demise of many of these clubs have been discussed in Marinell Ash, The Strange Death of Scottish History (Loanhead, 1980) [Ash, The Strange Death].

${ }^{3}$ The obvious exception to this being the editors of the Regesta Regum Scottorum series. Royal charters, however, only form a small percentage of the documents in volumes published by these clubs.
} 
article these issues will be examined in detail for the first time using the Moray cartulary as particularly stark case study.

\section{THE BANNATYNE CLUB, 1823-67}

The Bannatyne Club was formally constituted in Edinburgh in February 1823, with Sir Walter Scott as the first president and his close friend Thomas Thomson as vicepresident. ${ }^{4}$ Thomson became the second president following the death of Scott in $1832 .^{5}$ Although both men were later regarded as the founding figures of the Bannatyne Club, ${ }^{6}$ the few surviving pieces of evidence relating to the preliminary discussions about forming a club indicate that Scott was central to the whole process. ${ }^{7}$ Indeed, Marinell Ash has argued that the formation of the Bannatyne Club was a manifestation of a historical revolution in Scotland inspired by the writings of Sir Walter Scott. ${ }^{8}$ The primary aim of the new club was the publication of works illustrative of the history, literature, and antiquities of Scotland, ${ }^{9}$ and these targets were flamboyantly set out in the following poem:

Here we are met, a club of Bannatynians, Pilgrims to Antiquity's deserted shore, Rescuers of tracts from oblivion's dominions, Wakeners of authors who begin to snore. ${ }^{10}$

Yet another strong rationale behind the formation of the Bannatyne Club may have been the fact that by the 1820s at least one club in England, the Roxburghe Club, was already producing texts aimed at preserving literary and historical manuscripts. ${ }^{11}$ There is also evidence that at least some of the future members of the Bannatyne Club had already

\footnotetext{
${ }^{4}$ Ash, The Strange Death, 47.

${ }^{5}$ Edinburgh, National Library of Scotland [NLS], MS 9357, 114.

${ }^{6}$ David Laing, The Bannatyne Club. Lists of members and the rules, with a catalogue of the books printed for the Bannatyne Club since its institution in 1823 (Edinburgh, 1867), 43 [Laing, The Bannatyne Club].

${ }^{7}$ Edinburgh, University of Edinburgh Library [EUL], La.IV.14/19/19.

${ }^{8}$ Ash, The Strange Death, 39-40.

${ }^{9}$ C. Terry (ed.), A Catalogue of the Publications of Scottish Historical and Kindred Clubs and Societies, and of the volumes relative to Scottish History issued by His Majesty's Stationery Office 1780-1908 (Glasgow, 1909), 26.

${ }^{10}$ Bannatyne Club, Notices Relative to The Bannatyne Club, Instituted in February, M.DCCC.XXIII. including critiques on some of its publications (Edinburgh, 1836), 57.

${ }^{11}$ Ibid., i-xiv.
} 
been privately printing some old manuscripts for distribution among themselves before 1823. ${ }^{12}$ In any event, the new Scottish club was named after George Bannatyne, the sixteenth-century collector of Scottish poetry, and at least one stanza to his memory was composed by the new Bannatynians. ${ }^{13}$

Assist me, ye friends of old books and old wine, In singing the praises of sage Bannatyne, Who left such a treasure of old Scottish lore, As enables each age to print one volume more! One volume more, my friends! one volume more! We will ransack old Banny for one volume more! ${ }^{14}$

This statement of intent was fully implemented. Of all the Scottish historical clubs that operated during the course of the nineteenth century the Bannatyne Club was the most prolific, publishing approximately 118 editions in forty-four years. ${ }^{15}$ To put this figure in context, the three Spalding Clubs that operated over a period of 119 years between 1841 and 1960 only managed to produce 105 texts. ${ }^{16}$

Although the number of members of the Bannatyne club was at first limited to thirty-one gentlemen, it soon became apparent that demand outweighed the actual number of places. Accordingly, in 1825 the upper limit of membership was raised to fifty. ${ }^{17}$ This again failed to satisfy demand and in 1827 the limit was further raised to one hundred, each member contributing five guineas annually towards the running costs of the club. ${ }^{18}$ Essentially, every member volunteered to become the patron of a proposed edition, see it

\footnotetext{
${ }^{12}$ Ibid., vi.

${ }^{13}$ Ibid., 30.

${ }^{14}$ Ibid., 4.

${ }^{15}$ David and Wendy B. Stevenson (eds), Scottish Texts and Calendars, an Analytical Guide to Serial Publications (Edinburgh, 1987), 17-38. This figure is approximate because there is at least one club publication that was not listed by the Stevensons. Also, my thanks to Grant G. Simpson for pointing out that most of the early material published by the Bannatyne Club was literary. After the death of Scott, possibly with the increasing influence of Thomas Thomson and Cosmo Innes, the publication of historical material increased.

${ }^{16}$ Ibid., 150-68. This total excludes publications that were not officially part of the club series.

${ }^{17}$ NLS, MS 9357, 17.

${ }^{18}$ Laing, The Bannatyne Club, 34.
} 
through to publication by providing sufficient funding either by himself or in tandem with others, and then present the finished product to the other members of the club. ${ }^{19}$

However, surprising though it may seem to our generation of scholars, the decision by this group of antiquarians to found a historical club in Scotland was not universally wellreceived by their contemporaries. Although the London Courier welcomed the creation of the Bannatyne Club, the Edinburgh Literary Gazette was rather less enthusiastic: 'This most ridiculous of all the affectations of the day has lately exhibited another instance of its diffusion, in the establishment of a Roxburghe Club in Edinburgh. ${ }^{20}$

In fact, some critics were very sceptical both about the whole project and the motivations of its members. An article in the April 1829 edition of the New Scots Magazine, for example, called the club 'this society for the diffusion of useless knowledge', and stated that the members were people:

[...] about whom nobody knows or cares. [...] A Bannatynian is a sort of literary scavenger, whose duty is to save from oblivion all kinds of rubbish. But, did ever men club together to promote objects so utterly useless? Was ever time and money more egregiously applied? What benefit is the public to derive from reprinting old trash $?^{21}$

There is no doubt that today people would wince with embarrassment upon receiving criticism of this nature. The Bannatyne Club, however, was collectively made of stronger stuff. They explained the criticism in the New Scots Magazine away by claiming that it had been written in a fit of pique by a gentleman who had failed in a bid to be elected as a member, and that it had been published without his permission. ${ }^{22}$ To their credit, the Bannatyne Club was not afraid to reprint criticisms like this in their own publications and this perhaps demonstrates an openness of mind together with a self-belief in their chosen

\footnotetext{
${ }^{19}$ Patrons also had potential volumes suggested to them: Edinburgh, National Archives of Scotland [NAS], Papers of the Loch family of Drylaw, GD 268/354/21.

${ }^{20}$ Laing, The Bannatyne Club, 8-9. The London Courier stated 'A new literary society has recently sprung up in Edinburgh, of the nature of the London Roxburghe Club, for the replication of scarce and valuable tracts, especially poetry'.

${ }^{21}$ Ibid., 57-8

${ }^{22}$ Ibid., xv.
} 
mission to preserve old documents in print for future generations. The club also adopted a pro-active stance towards the collection of older material. In 1827 the Bannatynians purchased a manuscript which was later printed as John Spalding's The History of the Troubles and Memorable Transactions in Scotland and England, from MDCXXIV to $M D C X L V$, originally out of the Troup library, from a bookseller in Aberdeen, for fifteen guineas. ${ }^{23}$ One year later, the club purchased 101 letters, written by Lady Margaret Burnet to John, duke of Lauderdale, from an Edinburgh bookseller for $£ 63$ 12s 6d. ${ }^{24}$

By 1840, however, it was clear that the club was in financial difficulty. While it retained an average annual surplus of approximately $£ 165$ for the first sixteen years of its life, the treasurer was forced to fight a constant battle with members reluctant to pay their yearly subscription of five guineas. Some years these arrears alone amounted to well over $£ 200$, close to half the annual income from membership subscriptions. Between 1840 and 1867 the club regularly made a loss and frequently had to call on its banking overdraft facility. This financial information demonstrates that the club members were obviously publishing above their means. Occasionally, they only managed to break even when money was received from the Maitland club to help with the publishing costs of editions like the Registrum Episcopatus Glasguensis. ${ }^{25}$

The financial affairs of the club seem to have reached breaking point in 1855 when there was a massive downturn in income and the committee was finding it very hard to convince candidates to accept membership when it was offered to them. Accordingly, that year David Laing wrote to every member to ask their opinion on the continuing viability of the club. Some of this correspondence has survived and from this it is clear that the vast majority of members voted to dissolve the club, albeit many with great reluctance (see Appendix 1, letter A). This downturn in income is reflected in the publication record: the Bannatyne Club produced approximately 93\% of its editions before 1855. After that date, the production of new texts slowed dramatically.

\footnotetext{
${ }^{23}$ NLS, MS 9360, 86; James Skene (ed.), The History of the Troubles and Memorable Transactions in Scotland and England, from MDCXXIV to MDCXLV. By John Spalding, 2 vols (Edinburgh, 1828-9).

${ }^{24}$ NLS, MS 9360, 103.
} 
This lack of sound finances after 1840 also occasionally strained the relationships between the club and the men who worked as editors for it. In December 1850, for example, Cosmo Innes wrote to David Laing about Origines Parochiales Scotiae and demanded that he should get more financial support from the club committee (see Appendix 1, letter B). Any worries Innes had regarding the continuing financial viability of the club also affected the attitudes of the clerks he employed to do the transcribing, collating, proof reading and indexing and some of them seem to have been concerned about their lack of job security (see Appendix 1, letters B and C).

Although the club subscriptions for 1856 were collected, they had been reduced to four guineas and this was the last occasion upon which members were asked to make an annual payment. Between 1856 and 1867, when publishing essentially ceased, no annual dues were called for and the club seems to have relied on the generosity of patrons to pay for new editions. In spite of these contributions, by 1866 the club only had $£ 60$ in its bank account and liabilities totalling $£ 350 .{ }^{26}$ This tale of financial woe, however, does not explain the whole picture. By the mid-1850s there also seems to have been a general air of malaise surrounding both the club and its activities. Around this time, one of the Bannatyne Club's most prolific editors, Cosmo Innes, became disenchanted with the ongoing work he was doing on behalf of his fellow members. For example, although sufficient funds of $£ 200$ had been secured from two patrons to complete Origines Parochiales Scotiae, Innes preferred to cease his involvement in that project 'because of the great labour and expense, and the want of general encouragement'. The club, lacking anyone willing to take on the final volume, repaid the money given to them by the Duke of Buccleuch and one other unnamed party. ${ }^{27}$

Marinell Ash, in her discussion of the gradual termination of Bannatyne Club activities during the 1850s, argued that the demise of the club was symptomatic of a wide decline

${ }^{25}$ EUL, SC5032: Bannatyne Club, The Abstracts of the Treasurer's Accounts From M.D.CCC.XXIII. to M.D.CCC.XXVIII. [EUL, Treasurer's Accounts]

${ }^{26}$ NAS, Papers of the Montague-Scott family, Dukes of Buccleuch, GD 224/1002/8.

${ }^{27}$ Ibid. 
in interest in Scottish national history as the Scots abandoned their preoccupation with the historical revolution begun by Sir Walter Scott. ${ }^{28}$ While some of the points made by Ash may be valid, she did not take account of the fact that the Bannatyne Club had been encountering severe financial difficulties since 1840. By the 1850s the club was finding it impossible to attract new members who were willing to throw money at an ailing institution in desperate need of new investment to pay off an overdraft. Accordingly, a major reason for the demise of the Bannatyne Club may quite simply have been financial reality.

The last two editorial contributions that Cosmo Innes made to the club were both published in 1856. These consisted of the second volume of the Arbroath cartulary and the two volumes of the Brechin cartulary. Even though they were not the last ecclesiastical cartularies published by the Bannatyne Club, they were the last relating to a major high medieval Scottish ecclesiastical establishment to appear in print during the nineteenth century.

\section{NINETEENTH-CENTURY PUBLISHED ECCLESIASTICAL CARTULARIES}

In total, approximately thirty-five Scottish ecclesiastical cartularies were published during the course of the nineteenth century. These publications are listed in Appendix 2, table 1 and can be divided into two broad groupings. The first of these groups contains what should perhaps be called 'true cartularies', since they were published either wholly or mostly from medieval manuscript-collections of documents relating to a single religious foundation. These include: Aberdeen, Arbroath, Blackfriars of Perth, Cambuskenneth, Coldstream, Dryburgh, Dunfermline, Glasgow, Inchaffray, Kelso, Melrose, Moray, Newbattle, Paisley, Scone, St Andrews, and St Nicholas (Aberdeen). The second group, whether nowadays classed as cartularies or not, should perhaps be referred to as 'artificial cartularies' since they have been either completely or almost completely assembled from scratch, using numerous different sources of documentary

\footnotetext{
${ }^{28}$ Ash, The Strange Death, 10-11, 84-5 and 150.
} 
material. This latter group includes the published material relating to the important institutions of Brechin, Crosraguel, North Berwick, and Holyrood. ${ }^{29}$

The latter grouping is perhaps the easier to deal with first. Everyone should be aware of the fact that they are largely artificial constructs. As such, the arrangement of the material within these editions is a product of a distinct editorial style in which royal material and a good solid chronological arrangement took precedence in accordance with nineteenthcentury antiquarian legal sensibilities. More importantly, perhaps, the major problem with this grouping of published material is that they inevitably do not include new documents uncovered since they initially went to print. Essentially, these artificial constructs are between 120 and 160 years out of date. While some attempts have been made at various times at least to place a few pieces of new material in the public domain, this has never been done in either a systematic or sustained manner. ${ }^{30}$

If we now turn back to the first grouping of published material, those cartularies that were wholly or almost wholly based on earlier manuscript cartularies, it is possible to subdivide them further into another two broad groups. First, those that were based chiefly on a single manuscript with supplementary material derived from other sources: this group includes the cartularies of Balmerino, Cambuskenneth, Coldstream, Crail, Holmcultram, Kelso, Lindores, Newbattle, and Paisley. ${ }^{31}$ Second, those that were based chiefly on multiple manuscripts, again with supplementary material derived from other sources. This second group includes the cartularies of Aberdeen, Arbroath, Dunfermline,

\footnotetext{
${ }^{29}$ Fragments of a manuscript for Holyrood, containing sixteenth-century documents, were used by Cosmo Innes in his published edition: Cosmo Innes (ed.), Liber Cartarum Sancte Crucis. Munimenta Ecclesie Sancte Crucis de Edwinesburg (Edinburgh, 1840), xlii. A small manuscript, amounting to $26 \%$ of the total number of printed documents, was also used as a basis for the published edition of Brechin: Cosmo Innes (ed.), Registrum Episcopatus Brechinensis cui accedunt Cartae Quamplurimae Originales, 2 vols (Edinburgh, 1856). The order of this material was changed and a small number of the documents were sourced from other collections because they were 'imperfect' in the small manuscript.

${ }^{30}$ For example: D. E. Easson (ed.), 'Miscellaneous Monastic Charters', Miscellany of the Scottish History Society, viii (Edinburgh, 1951), 3-16; W.W. Scott (ed.), 'Eight thirteenth-century texts', Miscellany of the Scottish History Society, xiii (Edinburgh, 2004), 1-41 [Scott, 'Texts'].

${ }^{31}$ Some of the documents in the Paisley manuscript were incomplete and Innes collated them with copies from another manuscript: Cosmo Innes (ed.), Registrum Monasterii de Passelet. Cartas privilegia conventiones aliaque munimenta complectens a domo fundata A.D.MCLXIII usque ad A.D.MDXXIX ad fidem codicis ms. in bibliotheca facultatis juridicae Edinensis servati nunc primum typis mandatum (Edinburgh, 1832), x-xi [Paisley Reg.].
} 
Glasgow, Melrose, Moray, St Andrews, and Scone. Half of the published versions of this second group of cartularies were produced from either two or three different medieval cartularies although this number could vary enormously. Arbroath and Dunfermline were each produced from at least three different manuscripts, Moray from six and Aberdeen from at least nine.

Naturally, the process of editing these often diverse manuscripts into a coherent printed cartulary posed a number of methodological problems for the editors. For example, upon the completion of the Aberdeen cartulary the editor, Cosmo Innes, dryly understated in his introduction: 'The arrangement of these materials was not unattended with difficulty; and it was found that scarcely any method could be adopted that would not be open to objections ${ }^{32}$ In fact, Innes's solution to the problem on this particular occasion was to assemble the bulk of the material from his nine manuscript sources thematically and then order them chronologically. In addition, he placed all the documents that he thought other people would find 'most interesting and practically useful' in the first volume. ${ }^{33}$ Although these may have seemed like logical solutions to Innes, it means that the published edition of the Aberdeen cartulary bears little resemblance to any of the manuscripts from which it was created.

A second methodological problem concerned the size of the published editions. It was an expensive undertaking to finance all of the work that went into each volume, and this may be why an editorial decision seems to have been taken to rank the surviving records according to age on the assumption that the earliest records were of greatest importance on a sliding chronological scale. This meant that in all of the larger published cartularies, all documents produced before 1400 were published in full. Thereafter, documents belonging to the reign of James II were abridged and 'greater liberties' were taken to

\footnotetext{
${ }^{32}$ Cosmo Innes (ed.), Registrum Episcopatus Aberdonensis. Ecclesie cathedralis Aberdonensis regesta que extant in unum collecta, 2 vols (Aberdeen, 1845), i. lxxiii. Innes was contemplating publishing a third volume of the Aberdeen cartulary in 1845. At present it is unknown why this idea was abandoned Mitchell Library (Glasgow) MS. 891061.

${ }^{33}$ Ibid., lxxxii.
} 
compress documents produced post- $1500 .{ }^{34}$ Statements of this nature should nowadays make any self-respecting historian cringe, but the nineteenth-century editors were clearly working within a radically different set of historical mores.

There is a small amount of evidence which demonstrates that Innes occasionally received gentle criticism from his peers. ${ }^{35}$ Shortly after the beginning of the twentieth century, however, it became apparent that a new generation of Scottish historians had greater reservations regarding both the editorial methodologies adopted by the historical clubs and the standards to which some of the documents had been transcribed. For example, in the preface to the new edition of the Inchaffray charters published for the Scottish History Society, the editorial team remarked that they '[...] found many charters which had not been entered in the register. And of those printed in the Bannatyne publication few, if any, were perfectly accurate in their reproduction'. ${ }^{36}$ An additional problem, not just in the case of Inchaffray, was that in the latter two decades of the nineteenth century new ecclesiastical material had also been discovered, either by accident or through research. Nevertheless, the new Inchaffray volume was one of only three attempts during the course of the next hundred years to improve on the job done by the historical clubs during the nineteenth century, possibly because professional historians realised only too well the exact scale of the task should a complete programme of revision ever be undertaken. ${ }^{37}$

It is probably correct to state that the sheer scope of this undertaking has been made all the greater through the activities of just one man: Cosmo Innes. Between 1832 and 1856

\footnotetext{
${ }^{34}$ For example: Cosmo Innes (ed.), Registrum Episcopatus Glasguensis: munimenta ecclesie metropolitane Glasguensis, a sede restaurata seculo inuente XII, ad reformatam religionem, 2 vols (Glasgow, 1843), i. xvi-xvii [Glasgow Reg.].

${ }^{35}$ Mitchell Library (Glasgow), MS. 891069. This is a letter from Joseph Robertson that questions readings, dates and editorial statements made by Innes in the Aberdeen cartulary.

${ }^{36}$ William Alexander Lindsay, John Dowden and John Maitland Thomson (eds), Charters, Bulls and other documents relating to the Abbey of Inchaffray, chiefly from the originals in the charter chest of the earl of Kinnoul (Edinburgh, 1908), v. The editor of the earlier Bannatyne Club publication, though largely reliant on a fifteenth-century cartulary, had tested the documents preserved in the cartulary against the originals and found the cartulary to be 'on the whole, faithful and accurate'. Cosmo Innes (ed.), Liber insule missarum. Abbacie canonicorum regularium B. Virginis et S. Johannis de Inchaffery registrum vetus: premissis quibusdam comitatus antiqui de Stratherne reliquiis (Edinburgh, 1847), xvi-xix.

${ }^{37}$ The other two are: John Dowden (ed.), Chartulary of the Abbey of Lindores, 1195-1479 (Edinburgh, 1903). Note comments at xciii-xcv; D.E. Easson (ed.), Charters of the Abbey of Coupar Angus, 2 vols (Edinburgh, 1947), i. Note comments at v-xi.
} 
he was either wholly or jointly responsible for editing or constructing fourteen of the ecclesiastic texts in Appendix 2, table 1: Aberdeen, Arbroath, Brechin, Dunfermline, Glasgow, Holyrood, Inchaffray, Kelso, Melrose, Moray, Newbattle, North Berwick, Paisley, and Scone. ${ }^{38}$ This is an impressive assemblage of work on most of the major religious houses of Scotland and it is unsurpassed by any other nineteenth-century editor of historical material working in Scotland. ${ }^{39}$ Given this, it may prove worthwhile to examine in greater detail the working practices used by Innes in order to try to reconstruct his editorial methodology.

\section{THE PHILOSOPHY AND PRACTICALITIES BEHIND EDITING AN ECCLESIASTICAL CARTULARY FOR THE BANNATYNE CLUB}

Cosmo Innes was elected as a member of the Bannatyne Club on 31 January 1829 at the third time of asking. His proposers were Thomas Thomson and J.A. Murray. Thereafter, he was elected to the club management committee on at least two occasions, in 1832 and $1836 .^{40}$ There are probably a number of reasons why Cosmo Innes edited so much material for the Bannatyne Club. First, the club members clearly regarded him as an expert in his field, though not at the same level as Thomas Thomson. ${ }^{41}$ Second, Innes himself must have been very enthusiastic about many of the projects since he either did not want or was not offered a retainer by the club for his services in editing the records of Paisley, Melrose, Moray, and Holyrood. ${ }^{42}$ Third, by February 1841 the other members of the club were aware that Innes was financially constrained and needed extra cash to support his large family. ${ }^{43}$ In this respect, the spring of 1841 was something of a turning

\footnotetext{
${ }^{38}$ [Katherine Burton], Memoir of Cosmo Innes (Edinburgh, 1874), 55 [Burton, Memoir]. The author, who was a daughter of Innes and married to John Hill Burton, stated that her father had edited the Scone cartulary. Katherine Burton is not actually named as the author in the memoir but the book is attributed to her by the new Oxford DNB (http://www.oxforddnb.com/articles/14428). Accessed 28 May 2006. My thanks to Grant G. Simpson for alerting me to the existence of this memoir.

${ }^{39} \mathrm{Ibid}$., 25. The memoir of Innes attributes this prodigious work-rate to the fact that he never slept for more than a few hours each night.

${ }^{40}$ NLS, MS 9357, at 59, 63, 67, 114 and 155.

${ }^{41}$ NAS, GD 268/129/17.

${ }^{42}$ NAS, GD 268/129/18-19x. Innes did, however, receive some money in return for his editorial services from at least one of the patrons of these editions, NLS DEP 313/776.

${ }^{43}$ NAS, GD 268/129/17. Innes seems to have had a total of nine children and he was removed from his position as Depute Advocate when the Whig government lost office in 1839. As a result, the family had to make economic concessions that involved renting out their townhouse in Edinburgh and moving to South Queensferry: Burton, Memoir, 19, 33.
} 
point in the relationship between Cosmo Innes and the Bannatyne Club. At this time he presented the club with a series of financial options by which he would receive payment for the next book he edited from the patron of that volume (see Appendix 3, letter D). After 1841 he usually requested, and received, payments in the region of $£ 100$ for each successive project placed in his care. ${ }^{44}$

It is a relatively easy task to locate a large part of Cosmo Innes's editorial philosophy. He set out much of this in the Maitland Club's publication of the Paisley cartulary in 1832, the first cartulary that he edited. His attitude towards ecclesiastical records seems to have changed very little during any of the succeeding volumes that he edited for the Bannatyne Club. ${ }^{45}$ In his introduction to the Paisley cartulary it is clear that Innes was an enthusiastic antiquarian, particularly from a legal viewpoint. As he was a practising advocate this attitude is unsurprising. Innes saw the church cartularies as valuable repositories of information on the development of conveyancing, feudal tenures, courts and the settlement of disputes. ${ }^{46}$ In addition, for Innes these records were also proof of the first step of civilisation in Scotland, as the native inferior races were gradually displaced by more energetic strangers. ${ }^{47}$

Innes, however, was not prepared to lend equal weight to each separate manuscript that he encountered. He divided them into two broad classes. First, those which he regarded as being of 'sufficient antiquity' because the palaeographic conventions matched the date of the document. Second, those where the manuscript source was a post-1600 transcript. This division is an important key to understanding another part of Innes's editorial methodology as he generally regarded these later transcripts as being packed full of 'manifest errors', 'misconceptions', and 'imperfections'. Therefore, to get rid of these problems the imperfect documents had to be collated with all other copies of the same document to improve their grammar and errors. When this approach did not work Innes excised the offending sections and replaced them with similar excerpts from different

\footnotetext{
${ }^{44}$ EUL, La.IV.17/4917.

${ }^{45}$ Paisley Reg., xix-xxiiii.

${ }^{46}$ Ibid., xxi.

${ }^{47}$ Ibid., xx. Innes's daughter stated that he was 'not at all partial to Highlanders': Burton, Memoir, 48.
} 
documents that he felt were grammatically superior to his faulty original. ${ }^{48}$ It does not appear to have occurred to Innes that a manuscript might contain two, perhaps slightly different, copies of the same document for a good reason. This approach was used by Innes throughout his career: for example, the letter from him to the Bannatyne Club about the proposed organisation of the published edition of the Arbroath cartulary refers to some aspects of this methodology (Appendix 4, letter E). It should be noted, however, that Innes was occasionally prepared to be flexible. On one occasion he abandoned this methodology because he decided that the later copy of a cartulary was grammatically superior to the older manuscript. ${ }^{49}$

The published edition of the Paisley cartulary is unique for a further two reasons. First, although it is not the only manuscript transcript that Innes edited, it is the sole example of his work that contains a list of all his editorial corrections that had been made to the texts for the published edition. Second, the Paisley cartulary remains the only example of Innes's editorial work where he appears to have published the documents in the order in which they appear in the manuscript. ${ }^{50}$

Five years later, in 1837, Innes completed his second manuscript for publication. This was the Melrose cartulary for the Bannatyne Club. ${ }^{51}$ There is some evidence that it had originally been planned to print this edition in 1832. However, in August of that year Innes was informed by Joseph Stevenson of a collection of Melrose charters in the British Museum and the inclusion of some of these may have delayed publication. ${ }^{52}$ More importantly, the production of this edition formed yet another important step in the

\footnotetext{
${ }^{48}$ Paisley Reg., xxii.

${ }^{49}$ Cosmo Innes (ed.), Registrum Episcopatus Moraviensis, e pluribus codicibus consarcinatum circa A.D.MCCCC. Cum continuatione diplomatum recentiorum usque ad A.D.MDCXXIII (Edinburgh, 1837), ii [Moray Reg.].

${ }^{50} \mathrm{He}$ partially followed this methodology in other published cartularies, like Arbroath and Dunfermline, before reverting to 'throwing together charters in chronological order', cf. Cosmo Innes and Patrick Chalmers (eds), Liber S. Thome de Aberbrothoc, 2 vols (Edinburgh, 1848 and 1856), i. xxxiv. By my count only $24 \%$ of the documents in the Arbroath cartulary were published in the same order as they were found in manuscript sources.

${ }^{51}$ Cosmo Innes (ed.), Liber Sancte Marie de Melros. Munimenta vetustiora monasterii Cisterciensis de Melros, 2 vols (Edinburgh, 1837), [Melrose Reg.].

52 NAS, Publications, including Record Commission, SRO 10/59/1. I am grateful to Dauvit Broun for pointing out that not all of the Melrose material was included in the published edition.
} 
editorial methodology employed by Innes because for the first time he was faced with editing three sources, comprising two different manuscripts and a collection of original single sheets. To make matters worse, according to Innes one manuscript was 'ancient' though fragmentary. The second was more complete but contained material as late as the reign of James IV (1488-1513). In accordance with the editorial philosophy he set out in the Paisley cartulary, in the case of Melrose Innes preferred to print transcripts of the original single sheets, except when he had to resort to using a 'superior' version present in either of the two manuscripts. ${ }^{53}$

There was, however, one important distinction. Whenever the second and later manuscript offered a 'manifestly better reading' of a particular document, Innes preferred to use it rather than the version found in the 'ancient' manuscript. ${ }^{54}$ This would not have been a problem had Innes ever defined what he meant by the phrase 'manifestly better reading' whenever he made a change to a document. Since he did not, the reader is left in the dark as to exactly why the 'ancient' version was rejected in the first instance. In total, Innes utilised the phrase 'manifestly better reading', or something similar, to justify collating different versions of the same document on numerous occasions in at least nine of his edited volumes: Arbroath, Aberdeen, Brechin, Dunfermline, Glasgow, Melrose, Moray, Newbattle, and Paisley. This means that an unknown percentage of material in the Bannatyne Club cartularies should now be treated as collations that may not replicate the original documents as they appear in the earliest manuscripts. ${ }^{55}$ Since few of Innes's published editions have ever been examined in detail against the original manuscripts or collections from which they were created, historians currently have no idea just how extensive this problem is. Unfortunately, it is not clear whether the decision to collate different manuscripts into one published version was taken collectively by the Bannatyne Club, or by Innes alone. However, since Innes was on the management committee of the Bannatyne Club by $1836,{ }^{56}$ this may be a moot point.

\footnotetext{
${ }^{53}$ Melrose Reg., i. vi-vii.

${ }^{54}$ Ibid., vii.

55 One example of this was highlighted by G.W.S. Barrow when he noted a discrepancy between the published and manuscript versions of a brieve issued by King David I: G.W.S. Barrow, 'De domibus religiosis: a note on Dornoch', Innes Review, 48 (1997), 83-4.

${ }^{56}$ NLS, MS 9357, 155.
} 
The problems with these published editions do not end here. Most of the surviving records relating to the meetings and workings of the Bannatyne Club can now be found in the National Library of Scotland and Edinburgh University Library, although there are obvious chronological gaps. Some of this material had already been lost before 1877 when a search was made of the surviving Bannatyne records for documents relating to the publishing of the Melrose cartulary. ${ }^{57}$ Furthermore, even without taking these lacunae into account, it is immediately clear that only a small percentage of the club records relating to their publications has survived. While this makes the process of trying to reconstruct the remainder of Innes's editorial methodology difficult, some further important points can be gleaned from the material.

The first general point to note is that the men employed as editors by the Bannatyne Club, across the whole range of its publications, were free to sub-contract pieces of work to other people as they saw fit. In fact, it looks as if this was probably the norm for the majority of the club publications and the records are packed either with instructions to the club treasurer to issue payments to clerks or with receipts of payment for services rendered. ${ }^{58}$ This does not seem to have been unusual in the nineteenth century. These records also indicate that the club kept returning to the same clerks, according to their expertise. Normally, their contributions, whether it was collation, transcription, indexing, proof reading or translation, was acknowledged by the editor of the book to which they contributed. ${ }^{59}$ None of the fourteen cartularies edited by Cosmo Innes for the Bannatyne, Maitland and Spalding Clubs contain any such references to sub-contracted work. ${ }^{60}$ This lack of acknowledgement might lead a modern reader, because of what we now understand by the word 'editing', to assume that Innes had done all of the hard work by himself. Such an assumption would be wrong.

\footnotetext{
${ }^{57}$ EUL, La.IV.15/88.

${ }^{58}$ NLS, MS 9360, at 2, 6 and 178; MS 9361, at 164, 166 and 192; MS 9362, at 4 and 14.

${ }^{59}$ For example David Laing (ed.), The Letters and Journals of Robert Baillie, A.M. Principal of the University of Glasgow. M.DC.XXXVII. - M.DC.LXII., 3 vols (Edinburgh, 1841), i. xi.

${ }^{60}$ Joseph Stevenson was another editor employed by the Bannatyne Club who did not acknowledge the contribution of the scribes who worked for him.
} 
In the club records there is more surviving material relating to the publication of the Glasgow and Arbroath cartularies than for any other. The information relating to Glasgow shows that Innes employed at least four clerks between 1839 and 1841 to work on and transcribe different parts of the various manuscripts and charters that eventually became the published edition of the Glasgow cartulary. These men were Robert Jamieson, who was paid twenty guineas, William Millar, paid £6 1s, R. Chambers, paid $£ 1$ 13s 4d, and James McPhail, paid $£ 7$ 7s. ${ }^{61}$ Innes himself was paid $£ 100$ as editor. ${ }^{62}$

Like the Glasgow cartulary, Innes employed at least three clerks for the Arbroath cartulary, John Rennie, George Melville and James B. Brichan. However, since the two volumes of this edition were published at separate times, 1848 and 1856, not all of these clerks were used simultaneously (Appendix 5, letter F). Innes also used the fact that the two Arbroath volumes were not published simultaneously to try to increase his share of any fee that the club might offer (Appendix 5, letter G), although the club committee seems to have rejected that proposal and Innes was paid a remittance of $£ 105$ for volume two in August $1854{ }^{63}$

The presence of these receipts and letters, together with the information they contain, allows a reconstruction of Innes's working methods in compiling the published editions of the Glasgow and Arbroath cartularies. First, after being approved as editor, ${ }^{64}$ he subcontracted most, if not all, of the transcribing work to other people. It may be assumed, even though there is no proof of this, that these sub-contractors were working to a common style-sheet. Otherwise, this would mean more work for Innes at a later date in the editorial process. It was also probably at this stage that many documents were abridged. Second, after receiving the various transcriptions, it looks as though Innes then sorted and arranged them both chronologically and/or thematically before rejecting the material that he did not want to include in the published edition. Third, the evidence implies that after this work had been done, the newly arranged transcriptions were

\footnotetext{
${ }^{61}$ NLS, MS 9361, 115; NLS, MS 9362, at 19, 21 and 28.

${ }^{62}$ EUL, Treasurer's Accounts (for 1841).

${ }^{63}$ EUL, La.IV.17/4931.

${ }^{64}$ EUL, La.IV.15/21.
} 
returned to a sub-contractor who then re-transcribed them into proofs and checked these against the original manuscripts, before submitting the proofs to Innes for approval before print-setting. ${ }^{65}$ The final stage in the process was the actual print run. After Innes began receiving money directly from the Bannatyne Club for editorial duties, there is no evidence that he was ever directly involved in transcribing, abridging, proof reading, indexing, collating, or constructing tabula for any of his publications. His sole responsibilities seem to have consisted of general and financial management, the regnal and chronological ordering of transcriptions, approvement of the final proofs, and the writing of the preface.

All of this raises the question of whether Innes ever actually worked with any of the source material from which his published cartularies were constructed. Surprising though this may seem there is some evidence to support such a belief. In his introduction to the Glasgow cartulary Innes made the following statement:

The fragment of the ancient Life of St Kentigern, written at the desire of Herbert Bishop of Glasgow, is printed from the only copy I have met with. The original is a very careless and ignorant transcript in a hand of the beginning of the $15^{\text {th }}$ century, with red initial letters. The unintelligible shape in which the scribe has left his work must excuse the attempt I have made to restore it nearer to the character which the original must have borne, and which I did not venture without the most careful collation of the MS. ${ }^{66}$

Although this passage gives the impression that Innes had consulted and transcribed the manuscript in person it is contradicted by two letters in the Bannatyne Club records:

\section{A. 13 Grays Inn Square}

May 31841

Sir, I send herewith a correct transcript of the fragment of the life of St Kentigern. [...] I find there are about fifty folios which will come to $£ 113 \mathrm{~s} 4 \mathrm{~d}$.

R. Chambers. ${ }^{67}$

\footnotetext{
${ }^{65}$ NLS, MS 9361, 115.

${ }^{66}$ Glasgow Reg., i. lix-1x.

${ }^{67}$ NLS, MS 9362, 21.
} 


\section{B. My Dear Craig,}

Will you have the goodness to remit this sum $£ 113 \mathrm{~s} 4 \mathrm{~d}$ to London to the address of the writer on account of the Glasgow Chartulary. I am annoyed at having to trouble you so often about his fees. [...]

19 May '41, C. Innes. ${ }^{68}$

Given what is known about nineteenth-century editorial practice, it seems safe to assume that Innes, unlike other editors for the Bannatyne Club, had reached some kind of accommodation with the people to whom he sub-contracted work so that he took all the credit (and criticism) for their work.

More importantly, the possibility that Innes may never have seen some of the different source materials from which the Glasgow and Arbroath cartularies were created adds at least one more layer of uncertainty to the trustworthiness of the published editions. ${ }^{69}$ Not only did Innes arrange them from transcriptions of different documents done by subcontractors, but he himself placed a great deal of trust in these same sub-contractors to do their jobs properly. For example, if he never saw the original manuscript of the Life of St Kentigern in London, how did he know that the transcription by Chambers was either complete or accurate? This long process of transcription, followed by collation and ordering, and then re-transcription for printing, could also help explain why documents were both completely omitted ${ }^{70}$ or almost omitted from the published edition of the Glasgow cartulary. ${ }^{71}$

While it might be objected that the records surrounding the editing and publication of the Glasgow and Arbroath cartularies concern only two of Innes's publications, there is also clear evidence that he used the same editorial methods in at least another five occasions. The fragmentary records that survive relating to Innes's editions of the charters of North Berwick, Inchaffray, Kelso, Moray and Newbattle show that various clerks were paid in

\footnotetext{
${ }^{68}$ Ibid., 22.

${ }^{69}$ This is further complicated in the case of Arbroath since there is an Arbroath cartulary in the British Library that was not known to Innes (British Library, MS Additional 33245).

${ }^{70}$ Scott, 'Texts', 1.

${ }^{71}$ Glasgow Reg., ci-cii.
} 
each case for transcribing, proof reading and indexing work. ${ }^{72}$ Although this represents only half of Innes's publications for these clubs, it is enough to suggest that transcriptions, indexes, tabula, collating and proof reading were routinely done for him by clerks.

What is obvious by now is that all fourteen of the ecclesiastical cartularies published by Innes for the Maitland, Bannatyne and Spalding Clubs are far from straightforward compilations. Many bear little resemblance to the layout of the original manuscripts from which they were constructed, since Innes clearly preferred to group documents by reigns for printing. Furthermore, it is now also obvious that an unknown percentage of the documents in these published editions have been altered in some way by the clerks who worked for Innes, either through collation or alteration of wording. Finally, in the original manuscripts an unknown percentage of documents were classed by Innes as late transcriptions and so worthy of severe abridgement. All this poses severe questions about the accuracy of almost all of the ecclesiastical cartularies edited by Innes. The potential extent of these questions can be gauged by examining how Innes coped with one of his greatest editorial challenges: the charters of the bishop of Moray. The Moray cartulary is also a useful case to examine in detail because there are virtually no surviving records in the Bannatyne Club papers relating to its production.

\section{THE MORAY CARTULARY: MANUSCRIPTS versus PUBLISHED EDITION}

Innes had both secured permission from the Bannatyne Club and financial backing from the Duke of Sutherland for the plan to publish a Moray cartulary before 17 June $1833 .{ }^{73}$ The project took almost four years to complete and Innes produced the published edition entitled Registrum Episcopatus Moraviensis in 1837, the same year as he published the Melrose cartulary. The records show that Innes employed at least one clerk on the Moray project, both to search for and to transcribe material. In addition, the firm employed to print the new Moray cartulary acted as though Innes was their employer, rather than the

\footnotetext{
72 NLS, MS 9362, at 73, 75 and 119; EUL, Treasurer's Accounts, accounts for 1846 and 1849; NAS, North West Securities Ltd. Papers of William MacKenzie, W.S., GD 271/173.

${ }^{73}$ NAS, SRO 10/59/2.
} 
Duke or his representatives, even though Innes was not paying their invoices out of his own pocket. ${ }^{74}$ Instead, the representatives of the Duke of Sutherland sent money to Innes, who then paid the bills associated with the project. ${ }^{75}$ Even though records relating to this edition are very scarce, there is enough evidence to suggest that Innes acted as editor, manager and facilitator for the Duke of Sutherland. As a reward for his efforts, the Duke sent Innes an unspecified number of copies of the newly published cartulary ${ }^{76}$

As far as the Bannatyne edition of the Moray cartulary was concerned, Innes largely based his text on three manuscripts, all of which are now kept in the National Library of Scotland. The first of these manuscripts was NLS, MS Adv. 34.4.10 which Innes labelled 'The ancient Cartulary of the Bishoprick of Moray', and which he regarded as having been written over a long period of time. According to him, the manuscript was composed of a number of gatherings, some of which had originally formed separate records. For example, he argued that the earliest gathering was written in a hand of the thirteenth century, while the last gathering engrossed deeds down to 1569. Innes then suggested that many of these gatherings had been collected shortly after 1394, in pursuance of a papal commission, because of the great damage done to Bishop Alexander Bur and the see of Moray by Alexander Stewart, Lord of Badenoch, in 1390. ${ }^{77}$

The second manuscript used by Innes was NLS, MS Adv. 34.4.9. He called it 'The Red Book of the Church of Moray' and argued that most of this manuscript was an exact copy of NLS, MS Adv. 34.4.10, completed sometime between 1488 and 1512. The remainder of the manuscript, according to Innes, consisted of post-1512 charters and writs relating to the dismemberment of the bishopric and the alienation of its lands. ${ }^{78}$ The final manuscript that Cosmo Innes used was NLS, MS Adv. 34.5.2. From this he published an account of the rental of the bishopric which he dated to 1565 , and bemoaned the fact that no earlier financial information had survived. By 1565, he argued, church property had

\footnotetext{
${ }^{74}$ NAS, GD 271/210.

${ }^{75}$ NAS, GD 271/237.

${ }^{76}$ NAS, GD 271/233.

${ }_{77}^{77}$ Moray Reg., i.

${ }^{78}$ Ibid., iiii-iv.
} 
been seriously dilapidated and it was likely that the value of church benefices had been deliberately underestimated to escape from onerous crown taxation. ${ }^{79}$

There are two fundamental problems with the editorial work undertaken by Cosmo Innes on these three manuscripts, particularly NLS, MS Adv. 34.4.10 and NLS, MS Adv. 34.4.9. The first of these is the way in which he ordered this material in his edition. The bulk of the documents from NLS, MS Adv. 34.4.10 and NLS, MS Adv. 34.4.9 were arranged by him both chronologically and thematically. Having rearranged the documents, Innes began with what he regarded as the Bishop's cartulary. He then published the charters of St Nicholas's Hospital, the muniments of Maison Dieu, charters concerning the bishop and the see, the convocations of canons, the endowments of chaplainries, altarages and vicarages, documents not concerning the diocese, lists of valuations and homages, writs inserted as styles for the scribes of the cathedral and, finally, a short chronicle of events in Scotland and England between 1390 and 1402. All of this was then followed by a mass of abbreviated deeds which relate to the bishopric in the fifty years preceding the Reformation, and a final section containing original charters which were included to illustrate either the antiquities of Moray or some of the deeds of local families with regard to the bishopric. ${ }^{80}$

This is a nice and tidy, though wholly artificial, arrangement and it has survived unchallenged by historians for 164 years. Appendix 6, table 2, however, will give some idea of just how different the arrangement of the first ninety-four documents in the Bannatyne Club edition of the Moray cartulary is in comparison to NLS, MS Adv. 34.4.10. In fact, only two out of 306 documents (excluding the Appendix and the Carte Originales) occur in exactly the same position as they appear in NLS, MS Adv. 34.4.10. More importantly, these artificial groupings completely disguise how the documents were arranged in the actual manuscripts.

\footnotetext{
${ }^{79}$ Ibid., vi.

${ }^{80}$ Ibid., v-vi. Innes also inserted four early Sutherland/De Moravia charters after his tabula. Presumably, this was for the gratification of the patron of this book, the Duke of Sutherland.
} 
In fact, out the 306 documents in the published edition of the Moray cartulary, twentyone documents (7\%) are not actually present in NLS, MS Adv. 34.4.10, though they can be found in the later manuscript NLS, MS Adv. 34.4.9. To complicate matters further, NLS, MS Adv. 34.4 .9 contains a small number of medieval documents, ranging in date from the thirteenth to the sixteenth centuries, that are not present in either NLS, MS Adv. 34.4.10 or the printed edition. This indicates that, contrary to what Innes thought, NLS, MS Adv. 34.4.9 is not an exact copy of NLS, MS Adv. 34.4.10.

Of course, this argument assumes that Innes was intimately familiar with these two manuscripts and that he was not relying on the opinion of a third party. ${ }^{81}$ If, however, all of the transcriptions were done for Innes by clerks who, though good Latinists and palaeographers, perhaps had no great experience of collating large manuscript collections and were getting paid very little for their work, it is easy to envisage different scenarios in which the belief that one of the manuscripts was an exact copy of the other might have arisen. Even if he had never personally examined both manuscripts in detail, presumably Innes would have had no reason to doubt the judgement of his scribe(s).

On one level this arrangement of documents from two different manuscripts is not surprising, given what we now know about Innes's editorial method. In the case of the Moray cartulary, however, there are perhaps other variables that should be taken into consideration. Innes was a person with strong personal ties to Moray: he was a member of the family of Innes of Innes and was appointed sheriff of Moray in 1840. His wife belonged to the Moray family of Rose of Kilravock. ${ }^{82}$ The Innes family could trace its descent from Berowald the Fleming who had originally been granted the lands of Inees and Etherurecard in Moray by King Malcolm IV on 25 December $1160 .{ }^{83}$ But if Cosmo Innes was personally biased in favour of tidily arranging the records of the see of Moray,

\footnotetext{
${ }^{81}$ In one of his letters Innes admitted to 'turning over' the pages of NLS, MS Adv. 34.4.10 one morning and to applying acid to the manuscript in an attempt to decipher some marginal notes that had caught his eye, NLS DEP 313/776. The tone of this letter does not suggest intimate familiarity with the manuscript. In contrast, none of his surviving correspondence ever refers to NLS, MS Adv. 34.4.9.

${ }^{82}$ http://www.oxforddnb.com/view/article/14428. Accessed 28 May 2006.

${ }^{83}$ C. Innes, Ane Account of The Familie of Innes compiled by Duncan Forbes of Culloden, 1698. With an Appendix of Charters and Notes (Aberdeen, 1864), 2; G.W.S. Barrow (ed.), Regesta Regum Scottorum, vol. i, (Edinburgh, 1960), no.175.
} 
the ancestry of his patron for this publication, the Duke of Sutherland, should also be taken into account. The nineteenth-century Dukes of Sutherland could also trace their ancestry back to an early Moravian settler. This was Freskin, who was granted Duffus and other lands in Moray by King David I. Freskin's immediate descendants took the surname, de Moravia. ${ }^{84}$ With ancestral links like these, it is perhaps understandable that Cosmo Innes would want to present the history and records of that see in a logical and organised manner for the gratification of himself, his family, and his patron.

The second problem with the published edition of the Moray cartulary is that NLS, MS Adv. 34.4.10, NLS, MS Adv. 34.4.9 and NLS, MS Adv. 34.5.2 are not the only manuscripts held by the National Library that contain material relating to the bishopric of Moray. The Hutton Correspondence, collected by General G.H. Hutton, contains a transcript of a manuscript from the Guthrie family archive which is now part of NLS, MS Adv. 29.4.2[x]. ${ }^{85}$ This consists of a fragmentary index and transcriptions of documents relating to the see of Moray, amounting to some 274 pages of material. What is unusual about NLS, MS Adv. 29.4.2[x] is that, in addition to many of the documents that are found in NLS, MS Adv. 34.4.10 and NLS, MS Adv. 34.4.9, it also contains material pertaining to the see of Moray which is not found in either of the other two manuscripts. The way in which the documents in NLS, MS Adv. 29.4.2[x] are ordered also differs from the arrangements found both in NLS, MS Adv. 34.4.10 and NLS, MS Adv. 34.4.9.

According to the National Library, all of the Hutton material was collected by Cosmo Innes in November 1851 and he left an inscription and many annotations upon NLS, MS Adv. 29.4.2[x]. This suggests that he would have encountered the manuscript long after the Moray cartulary had been published. However, Innes had been given the fragmentary index from the Guthrie family archive by a 'common friend' before June 1833 and this inspired him promptly to secure permission personally to examine the archive in the hope

\footnotetext{
${ }^{84}$ The original grant has not survived. However, a direct reference to it is made in a charter issued by King William I to William son of Freskin: G.W.S. Barrow (ed.) with W.W. Scott, Regesta Regum Scottorum, vol. ii, (Edinburgh, 1971), no.116.

${ }^{85}$ John Guthrie, an ancestor of the family, had been bishop of Moray between 1623 and 1639: D.E.R. Watt and A.L. Murray, Fasti Ecclesiae Scoticanae Medii Aevi Ad Annum 1638 (Edinburgh, 2003), 283.
} 
that it might contain more Moravian material. ${ }^{86}$ Innes spent a lot of his spare time visiting family archives in Scotland so there is little reason to doubt that he did not visit the Guthrie archive. Even if he failed to locate the main portion of the manuscript that was later transcribed and designated NLS, MS Adv. 29.4.2[x] in the 1830s, it might seem remarkable that Innes should not have drawn attention to this manuscript in one of his many later publications.

In any event, the introduction to the published edition of the Moray cartulary gives an indication of some of the problems Innes encountered when he edited NLS, MS Adv. 34.4.10, NLS, MS Adv. 34.4.9 and NLS, MS Adv. 34.5.2, and his method of dealing with them. For example, whenever he thought that records had been engrossed unsatisfactorily in these three manuscripts, Innes attempted to find copies of the particular documents in other sources and used those versions for publication in the Moray cartulary. ${ }^{87}$ Unfortunately, however, when he did utilise a version of a document from another source, he gave no indication how dissimilar it was to the version recorded in any of the three Moray manuscripts.

In a similar fashion, if Innes regarded the text of a particular document in the earliest manuscript, NLS, MS Adv. 34.4.10, as 'corrupt' (grammatically incorrect), he frequently found that the text of the later copy of that document, in NLS, MS Adv. 34.4.9, offered a grammatical improvement on the original. ${ }^{88}$ In these instances he invariably used text from the later manuscript for the published edition of the Moray cartulary. Of course, the problem with this approach to editorial work is that Innes effectively published copies of textually improved copies of copies of original documents. Often, these textually improved versions can be dated to almost 300 years later than the originals that they purport to record.

\footnotetext{
${ }^{86}$ NLS, DEP 313/776. The inscription left by Innes on NLS, MS Adv. 29.4.2[x] demonstrates that he had been given the index by Mrs H. Baxter. Since General Hutton is thought to have stopped collecting material in 1822, this indicates that another person, possibly Innes, added the transcripts of both the index and the manuscript to the Hutton collection at a later date. It is also clear that the index and the main manuscript had been separated before the 1830s.

${ }^{87}$ Moray Reg., ii.
} 
Yet another major problem encountered by Innes was choosing which documents to print from a particular manuscript. Frequently, manuscripts NLS, MS Adv. 34.4.10 and NLS, MS Adv. 34.4.9 preserve more than one copy of the same deed. These copies very often differ in the minute details that they preserve, such as in names included in witness lists. Innes (assuming that it was him that performed this task and not a scribe) circumvented this problem by choosing the version of a document that he thought was best preserved and collating this version with all the other copies he had at his disposal. ${ }^{89}$

A document that records a royal confirmation of an earlier grant by Bishop Brice (120322) of the church of Kingussie and the chapel of Banchor is a good example of this process. This document is preserved in NLS, MS Adv. 34.4.10 on three occasions. On the first the beneficiary is named as Gyllebertus de Kathern' and the deed is witnessed by Willelmo capellano meo, Willelmo de Bosco, Hugone de sigillo clericis meis, Hugone Freskin et fratre eius. On the second occasion the beneficiary is named as Gillebertus de Kathkerd and the witnesses are Willelmo capellano meo, Willelmo de Bosco et Hugone de sigillo clericis meis, Hugone freskin et Willelmo fratre eius. In the final version of this document the beneficiary is named Gillebertus de Kathert and the witnesses are named as Willelmo capellano meo, Willelmo de Bosco et Hugone de sigillo clericis meis, Hugone Freskin et fratre eius..$^{90}$ After collating these three different documents, in his edition Innes named the beneficiary as Gyllebertus de Kathern' and gave the following witness list: Willelmo capellano meo, Willelmo de Bosco et Hugone sigillo clericis meis, Hugo Freskin et Willelmo fratre ejus.

From this example, it is clear that the version of this confirmation published in the Bannatyne Club edition of the Moray cartulary is inaccurate. It does not preserve the precise personal names as they appear in any of the three originals. A second problem is that these multiple copies of documents in NLS, MS Adv. 34.4 .10 can also preserve different place-names. One example of this is a document recording an agreement in

\footnotetext{
${ }^{88}$ Ibid., iv.

${ }^{89}$ Ibid., iv.

${ }^{90}$ NLS, Advocates Library Manuscript, MS Adv. 34.4.10, fos.15r, 38r and 39v. All contractions have been silently expanded and names capitalised. Scribal grammatical errors have also been silently corrected.
} 
1226 between the bishop of Moray and W. de Petyn (of Petty). The first instance of this document in the manuscript reads: [...] super terris de Artendol Luninn et de Duldaui et Croyn [...] Et super aduocacionem ecclesiarum de Croyn et de Aberlouer Butbrothy et Artendol et super decima cani domini regis quod idem Rex solebat recipere de Bracholy et Aberlour et Kynemoneth [...]. The second adds to the last sentence the place-name Bucharm: [...] super terris de Ardtrillen et Lunyn et Duldaui et Croyn [...] et super aduocationem ecclesiarum de Croyn Abirlour Buchtruthyn et de Arteldol et super decima cani domini Regis quod idem rex solebat recipere de Bracholyn Bucharem Abirlochyn et Kyneremoneh [...]. ${ }^{91}$ When it came to publishing this document Innes (if indeed it was his choice) picked the second version with the additional place-name without explaining why.

Perhaps a more worrying example concerns the witness list of a document that preserves a record of a 1206x21 agreement between the bishop of Moray and John Bisset over the churches of Conveth and Wardlaw. There are three copies of this document in NLS, MS Adv. 34.4.10 and two different witness lists. In the first version the witness list runs: Testibus magistro Gylberto Archidiacono Moravie Andrea cancellario magistro Henrico thesaurario magistro Edwardo Roberto canonicis ecclesie sancte trinitatis de Spyni Roberto Willelmo Stephano Capellanis Arnulpho Byseth Arkembaldo de Duffus Hugone Corbet Alexandro et Henrico de Duglass Willelmo Byset Stephano de Edenham Willelmo Byset Radulpho parsona de Butruthen Willelmo senescallo Wadyno Gamelo Hucyngo marescallo et aliis.

The second version of the witness list is: Testibus magistro Gilberto Archidiacono Moravie Andrea Cancellario magistro Edwardo Roberto Canonicis ecclesie sancte trinitatis de Spyni Willelmo Stephano Roberto capellanis Arnulpho Byseth Archebaldo Hugone Corbeth militibus Willelmo Byseth Gylletalargyn et aliis.

The final version of the witness list is almost identical to the first: Testibus magistro Gilberto archidiacono Moravie Andrea cancellario magistro Henrico thesaurario

${ }^{91}$ Ibid., fos.15r and 39r. 
magistro Edwardo Roberto canonicis ecclesie sancte trinitatis de Spyni Roberto Willelmo Stephano capellanis Arnulpho Byseth Arkembaldo de Duffus Hugone Corbet Alexandro et Henrico de Duglas Willelmo Byset Stephano de Edinham Randulpho parsona de Butruthen Willelmo senescallo Wadino Gamello Hucting marescallo et aliis. ${ }^{92}$

In fact it was the second version of these witness lists that was chosen for the published edition of the Moray cartulary: [...] Testibus magistro Gilberto archidiacono Moravie Andrea cancellario magistro Edwardo Roberto canonicis ecclesie sancte Trinitatis de Spyni Willelmo Stephano Roberto capellanis Arnulpho Byseth Archebaldo Hugone Corbeth militibus Willelmo Byseth Gylletalargyn et aliis. ${ }^{93}$ As in other similar cases, Innes gave no indication why this version was preferred over the other, although this assumes that he was personally aware of the alternative version of the witness list in the first instance. The decision to reject one version in favour of another may, however, have been made by a clerk.

Potentially, all this means that in every case where Cosmo Innes and his clerks were working from multiple manuscripts, and where there are known to be multiple copies of the same document, the final published version of that may either never exactly replicate any of the copies or there may be an alternative unpublished version of the same document replete with significant variations in wordage and in the spelling of placenames. The extent of this problem is presently unknown, but if the numerous examples in the published Moray cartulary are multiplied across all of the editions that Innes produced, the scale could be quite large.

\section{SUMMARY}

Although historians working in the field of medieval Scotland have every reason to be grateful to the historical clubs for working to produce published editions of the surviving ecclesiastic documents, these books should now be recognised as being of limited value as sources of primary evidence. Many of them, particularly those produced by the

\footnotetext{
${ }^{92}$ Ibid., fos. $18 \mathrm{v}, 28 \mathrm{v}$, and $42 \mathrm{v}$.

${ }^{93}$ Moray Reg., 59.
} 
Bannatyne Club, are in some fashion artificial constructs. They have either been built out of disparate holdings of documents or collated from one or more manuscripts. While these artificial constructions were obviously acceptable to historians of that period, they were clearly working within a radically different set of principles.

The recognition that these published cartularies are in many senses artificial constructs is not enough, however, as there are additional problems. For example, an unknown number of documents have themselves been collated from multiple copies. Since, with the exception of the Paisley cartulary, the reader is never informed what changes have been made in the published editions, it means that in an ideal world every one of these documents must now be identified and checked against the original manuscript source(s) before it can be quoted as evidence. Perhaps even more worryingly, an unknown number of documents have had missing clauses inserted, copying language from other documents not related in either time or space to the original. Moreover, in almost all cases the rearrangement of the documents in the manuscripts for printing has acted to conceal both the original ordering of these documents in the original manuscript sources and what that arrangement might tell us, for example, about the ways in which material was gathered for that manuscript in the first instance.

It is, however, quite another matter to arrive at a solution to all these problems. Clearly, historians cannot continue to accept and use these published editions as primary sources in their own right. In an ideal RAE-less world it might be possible to begin work on trying to rectify the problems but this is unlikely to happen as long as monographs continue to be of prime importance to research assessment exercises. The irony of this tale is that some of these monographs may be based on misleading evidence if it was sourced from a published cartulary in the first instance. In this respect, perhaps the last word should rest with Cosmo Innes. To give him credit, it would appear that he was not completely happy with some of his published editions. For example, the introduction to the main body of text in the Moray cartulary contains a quite remarkable editorial disclaimer: 
The accurate student of these antiquities should not take such readings on the authority of an editor; [...] Where mistakes have occurred they cannot be attributed to haste or inadvertency. To bring the cartulary into its present shape has cost much time and labour. Unhappily, the thought will sometimes intrude that they might have been better bestowed. ${ }^{94}$

For how much longer can we afford to ignore this sentiment?

\footnotetext{
${ }^{94}$ Ibid., xlvii-xlviii.
} 


\section{APPENDIX 1, letters A, B \& C.}

A. $\quad$ Yair - Selkirk $19^{\text {th }}$ January 1855

Dear Mr Laing

I have received your report $\&$ circular relative to the proposal for winding up the Bannatyne Club. If I am in town on the $30^{\text {th }}$ I will attend the meeting, but in case I am prevented from doing so, I now write to say that I quite approve of the proposal. the reasons alleged for it appear to me quite conclusive. For some time past when I have observed on the shelves of my library to what a load the publications have reached it has frequently occurred to me that their value must be diminishing on account of their unwieldiness, and that even if the system is to be carried on it would be better to do it under a new name. My chief regret would be the discontinuance of the chartularies and other monastic records, for the perpetuation of which we had done more than any other similar association. But that consideration does not weigh against the valid arguments for slaying Banny before he becomes a victim to senility.

I am, my dear Sir very truly yours,

Alex. Pringle. ${ }^{95}$

B. 5 December 1850

Dear Mr Laing,

I venture to put you in mind of writing to the contributors to the Parochiale. My best assistant intimates that he is tempted to leave Edinburgh and I cannot secure help if I have not a certainty of remunerating the men who work for me. I daresay you can guess that, having exhausted the Contribution of the three members, for the Printer \& $\mathrm{Mr}$ Anderson - and having since employed three other gentlemen under myself - it is not a very lucrative concern for me. In prudence I know I ought to abandon it, but I think it useful and I will give my labour of you don't throw impediments in the way. Unless the committee support me, the book must stop.

Yours faithfully, C. Innes. ${ }^{96}$

C. Mr Edwards' 16 Scotland Street Edinburgh

19 April 1853

[...] But it would be wrong in me to conceal my conviction founded not only on my own experience but also on that of others, that a less charge will not bring the remuneration necessary for inducing parties to continue in this employment - uncertain employment at the rate of $10 / 6$ per day cannot produce more than $£ 80$ a year. [...] I now feel it would be for me to enter an office where regular employment brings assured and regular pay and leads to better remuneration [...] Mr Gilchrist is proceeding with his transcripts slowly - I have compared some of his work and considering his short experience, I must say that he works very well and with considerable care. [...]

Faithfully yours Francis Thom. ${ }^{97}$

\footnotetext{
${ }^{95}$ EUL, La.IV.14/19/6.

${ }^{96}$ EUL, La.IV.17/4918.

${ }^{97}$ NAS, Papers of the Campbell family of Barcaldine, GD 170/3009/9/1.
} 


\section{APPENDIX 2: table 1, nineteenth-century publications. ${ }^{98}$}

\begin{tabular}{|c|c|c|}
\hline $\begin{array}{l}\text { Club and Subject } \\
\text { Abbotsford Club }\end{array}$ & Editor & Date \\
\hline Sciennes & James Maidment & 1841 \\
\hline Balmerino and Lindores & William Turnbull & 1841 \\
\hline \multirow{2}{*}{\multicolumn{3}{|c|}{ Archaeological Association }} \\
\hline & & \\
\hline Ayr Friars & Robert W. Cochrane-Patrick & 1881 \\
\hline Crosraguel & F.C. Hunter Blair & 1886 \\
\hline \multicolumn{3}{|l|}{ Bannatyne Club } \\
\hline Melrose & Cosmo Innes & 1837 \\
\hline Moray & Cosmo Innes & 1837 \\
\hline Holyrood & Cosmo Innes & 1840 \\
\hline St Andrews & Thomas Thomson & 1841 \\
\hline Dunfermline & Cosmo Innes & 1842 \\
\hline Glasgow* & Cosmo Innes & 1843 \\
\hline Scone* & Cosmo Innes & 1843 \\
\hline Kelso & Cosmo Innes & 1846 \\
\hline Dryburgh & William Fraser & 1847 \\
\hline North Berwick & Cosmo Innes & 1847 \\
\hline Inchaffray & Cosmo Innes & 1847 \\
\hline Arbroath & Cosmo Innes \& Patrick Chalmers & $1848-56$ \\
\hline Newbattle & Cosmo Innes & 1849 \\
\hline Brechin & Patrick Chalmers \& Cosmo Innes & 1856 \\
\hline St Giles & David Laing & 1859 \\
\hline Soutra & David Laing & 1861 \\
\hline \multicolumn{3}{|l|}{ Grampian Club } \\
\hline Cambuskenneth & William Fraser & 1872 \\
\hline Glasgow: protocols and rental & Joseph Bain \& Charles Rogers & 1875 \\
\hline Beauly & Edmund Batten & 1877 \\
\hline Crail & Charles Rogers & 1877 \\
\hline Coldstream & Charles Rogers & 1877 \\
\hline Cupar-Angus & Charles Rogers & $1879-80$ \\
\hline Chapel-Royal & Charles Rogers & 1882 \\
\hline \multicolumn{3}{|l|}{ Maitland Club } \\
\hline Paisley & Cosmo Innes & 1832 \\
\hline Glasgow Blackfriars \&c. & Joseph Robertson & 1846 \\
\hline \multicolumn{3}{|l|}{ Private editions } \\
\hline Pluscarden & S.R. Macphail & 1881 \\
\hline Blackfriars of Perth & R. Milne & 1893 \\
\hline \multicolumn{3}{|l|}{ Scottish Antiquaries } \\
\hline Isle of May & John Stuart & 1868 \\
\hline Kinloss & John Stuart & 1872 \\
\hline \multicolumn{3}{|l|}{ Spalding Club } \\
\hline Aberdeen \# & Cosmo Innes & 1845 \\
\hline St Nicholas (Aberdeen) & James Cooper & $1888-92$ \\
\hline
\end{tabular}

\footnotetext{
${ }^{98}$ Publications jointly issued by the Bannatyne and Maitland Clubs have been indicated '*'. The Maitland Club also jointly issued the Aberdeen volume with the Spalding Club and this has been indicated 'fl'.
} 


\section{APPENDIX 3, letter D.}

[Undated, but must have been written between 10 and 16 February 1841.]

My dear Craig,

I had your note last night and have thought on the subject.

You know I am just done of Holyrood, \& I had pleased myself with the idea of working on the chartularies of Glasgow \& Dunfermline, both very important to me \& interesting.

On a reasonable calculation they would occupy my spare time at least for two years, \& there is no occupation within my reach that I should so much like.

But I feel that in my circumstances I have no right to give as large a portion of time for the benefit of others \& my own gratification, unremunerated. That I have done so before, first in Paisley, and then in Melros, Moray \& Holyrood, is an additional reason why I should not again be so foolish.

At the same time, all qualities considered, I believe I can do this kind of work better than anyone else that can be had, and I should be sorry that a really national work should be put into worse hands, or be stopped.

If I might suggest, there are two ways in which the matter may be done.

1. Adopt a plainer way of getting up the chartularies and let that part of the expense which at present goes to artists, be appropriated as a remuneration for the editor. Or

2. Where the sum intended for the book is not exactly limited, let the editor have a definite allowance; and let the illustrations \& embellishments be subject to the discretion of the contributor.

To adapt these plans to the present case, I should be willing to undertake to furnish the chartulary of Dunfermline, well \& scholarly edited and printed \& ready for the binder, but without ornament of any kind, for the sum $£ 300 \mathrm{Mr}$ Loch mentions; \& on that footing I should have for my own trouble something under $£ 100$. Or on the other plan / which I prefer / I will take $£ 100$ for my work as editor, and will have the necessary work of transcribing, printing \& indexing, done as economically as possible, \& submit any plans of embellishment by facsimiles \&c. to the after consideration of the Contributors.

Will you let Mr Loch know my views in this matter, and tell me whether he approved.

He will be pleased to hear that Holyrood will be out of the printers hands in eight days. My preface has run to an unexpected length, but a good deal of the matter is useful \& new. Lord Jeffrey says the fault of our chartularies is that they are still too much a sealed book to the uninitiated, \& he advises an explanatory title to each document, footnotes of any difficulties, and long prolegomena on the points of information \& interest to be found in the record. I fear the prolegomena to Holyrood will meet his views as to length at least.

I am dear Craig yours faithfully, C. Innes. ${ }^{99}$

${ }^{99}$ NAS, GD 268/129/18-19x. 


\title{
APPENDIX 4, letter E.
}

\begin{abstract}
15 March '47
My dear Sir,

The older Register of Arbroath will print to about 36 sheets, exclusive of indexes and prolegomena, or about 50 sheets including all necessary apparatus. The Later Register fills 1300 pages of transcript (144 words to a page) but a considerable part of it will be abridged, and I calculate it may be reduced to a volume (including tables and indexes) of 80 sheets or 640 pages. But you will observe "the Clerks copy" at Panmure has a few charters in the first vol. which are not in either of ours. The second vol. contains the charters of Abbot George Hepburn 1503-1515. It is a $12^{\mathrm{mo}}$ of 100 folios. The third vol. contains the charter of James and David Betouns, Abbots, and is a large octavo of 216 folios. 1518-1536. None of these are in ours. Of course the two last consist mostly of feu charters \& tacks, which though most valuable for local history will bear great abridgement. I count on having from Panmure, Kinnaird \& Cortachie, 50 to 60 illustrative documents, part of which will thole abridgement. Now all this brings me to the result, that we can make a much better division than by printing merely the Registr. Vetus by itself. There are some charters in the Later Register of our library as early as William the Lion (the founder) \& the Alexanders; and I think it would be much the most satisfactory way to arrange all the materials of the Registers somewhat after the method of the Glasgow Chartulary, \& at any rate in chronological order. If this arrangement is approved of, we could have two volumes of pretty equal size, each containing 70 or 80 sheets. There is no reason for undertaking more than one at present. You wished me to note the rate of remuneration we spoke of. I told you Mr I. Stevenson charged 2 Guineas a sheet for mere transcribing \& printing Latin documents, \& I proposed to follow that rate, exclusive of copying (which is done already) but including the labour of arranging, abridging \& preface etc. Now however I have rather changed my mind. I should not like to charge by the size - having the power of making the book bigger or less according to my judgement. I propose therefore that the Club should give me 100 Guineas for the first vol calculated to contain half the materials of the whole Registers of Arbroath. I think the Club must also allow $£ 20$ for a Clerk to collate, abridge, fetch \& carry. But if you think this too much for a Clerk's allowance, make it what you say is right and I will make it up to what will maintain the lad who works for me.

Faithfully yours, C. Innes. ${ }^{100}$
\end{abstract}

${ }^{100}$ EUL La.IV.17 (Cosmo Innes 1.), fo.4905. 


\section{APPENDIX 5, letters F \& G.}

\section{F. 3 Duncan Street 15 June ' 53}

Dear Sir,

I have given the matter of the new Arbroath volume my best consideration and the following is the result.

1. Rennie's MS. requires to be abridged and faithfully collated with the original.

2. It has to be seen at least twice in proof before going to press.

3. The additional matter contained in the two later volumes of the Chartulary and in charters already procured or to be procured requires to be copied for press, and abridged in copying.

4. It has to be seen at least twice in proof.

5. There must necessarily be a good deal of time spent in various ways in setting up the work - which cannot by any possibility enter into any calculation.

I do not know how many pages the Club would wish the volume to extend - but, supposing it to contain 600 pages of text, I am willing to undertake the work for $£ 150$. In this estimate I include the Tabula, but exclude the Index, which will require to be paid for separately. of course I understand that in proportion as the volume may fall short of or exceed 600 pages of texts, the estimate will be proportionally diminished or increased.

I am dear Sir ever yours faithfully,

James B. Brichan. ${ }^{101}$

G. $\quad 2^{\text {nd }}$ Division 28 June 1853

Dear Sir,

I need not say that I am very desirous to see the remaining volume of the Chartulary of Arbroath published. I think it one of the most important volumes the Club has undertaken. But, anxious as I am for its publication, I cannot afford so large a portion of my time as it will require, altogether without remuneration. I propose, with the approval of the Committee, to take Mr Brichin in my own hands, which I believe he will be willing to allow me to do, and to make a definite undertaking to see the whole editorial work transcribing, collating, abridging, searches, correcting the press, and writing preface, for Two hundred Guineas. I except from this the making of an Index, the expense of which you can easily estimate. [...]

Yours faithfully, C. Innes. ${ }^{102}$

${ }^{101}$ Ibid., fo. 4925 .

${ }^{102}$ Ibid., fo. 4929. 
APPENDIX 6: table 2, different arrangement of documents in the manuscript and published source.

\begin{tabular}{|c|c|c|c|}
\hline $\begin{array}{c}\text { Bannatyne Club } \\
\text { edition document } \\
\text { number }\end{array}$ & $\begin{array}{c}\text { Corresponding NLS, } \\
\text { MS Adv. 34.4.10 } \\
\text { document number }\end{array}$ & $\begin{array}{c}\text { Bannatyne Club } \\
\text { edition document } \\
\text { number }\end{array}$ & $\begin{array}{c}\text { Corresponding NLS, } \\
\text { MS Adv. 34.4.10 } \\
\text { document number }\end{array}$ \\
\hline 1 & 126 & 48 & 12 \\
\hline 2 & 29 & 49 & 11 \\
\hline 3 & 119 & 50 & 75 \\
\hline 4 & 131 & 51 & 88 \\
\hline 5 & 38 & 52 & 25 \\
\hline 6 & 110 & 53 & 67 \\
\hline 7 & 122 & 54 & 66 \\
\hline 8 & 123 & 55 & 20 \\
\hline 9 & 47 & 56 & 14 \\
\hline 10 & 127 & 57 & 23 \\
\hline 11 & 109 & 58 & 24 \\
\hline 12 & 44 & 59 & 73 \\
\hline 13 & 46 & 60 & 70 \\
\hline 14 & 26 & 61 & 84 \\
\hline 15 & 41 & 62 & 82 \\
\hline 16 & 118 & 63 & 91 \\
\hline 17 & 121 & 64 & 71 \\
\hline 18 & 31 & 65 & 69 \\
\hline 19 & 37 & 66 & 72 \\
\hline 20 & 125 & 67 & 21 \\
\hline 21 & 51 & 68 & 74 \\
\hline 22 & 117 & 69 & 8 \\
\hline 23 & 52 & 70 & 79 \\
\hline 24 & 115 & 71 & 92 \\
\hline 25 & 32 & 72 & 93 \\
\hline 26 & 48 & 73 & 86 \\
\hline 27 & 53 & 74 & 90 \\
\hline 28 & 54 & 75 & 87 \\
\hline 29 & 33 & 76 & 27 \\
\hline 30 & 36 & 77 & 77 \\
\hline 31 & 35 & 78 & 15 \\
\hline 32 & 39 & 79 & 85 \\
\hline 33 & 50 & 80 & 81 \\
\hline 34 & 34 & 81 & 2 \\
\hline 35 & 49 & 82 & 10 \\
\hline 36 & 45 & 83 & 57 \\
\hline 37 & 40 & 84 & 6 \\
\hline 38 & 43 & 85 & 56 \\
\hline 39 & 55 & 86 & 58 \\
\hline 40 & 42 & 87 & 89 \\
\hline 41 & 76 & 88 & 59 \\
\hline 42 & 28 & 89 & 78 \\
\hline 43 & 68 & 90 & 9 \\
\hline 44 & 95 & 91 & 4 \\
\hline 45 & 22 & 92 & 7 \\
\hline 46 & 1 & 93 & 3 \\
\hline 47 & 13 & 94 & 80 \\
\hline
\end{tabular}

